\title{
ISOLATION AND CHARACTERIZATION OF PSEUDOMONAS AERUGINOSA BACTERIOPHAGES - POTENTIAL AGENTS FOR PHAGE THERAPY
}

Kornienko MA $\bowtie$, Kuptsov NS, Danilov DI, Gorodnichev RB, Malakhova MV, Bespiatykh DA, Veselovsky VA, Shitikov EA, llina EN

Federal Research and Clinical Center of Physical-Chemical Medicine of Federal Medical Biological Agency, Moscow, Russia

Pseudomonas aeruginosa - is one of the pathogens characterized by the critical number of multidrug-resistant (MDR) strains. Phage therapy is considered an alternative to antibiotics, especially in treatment of infections caused by MDR strains. The aim of this study was to isolate and characterize $P$. aeruginosa phages that could potentially be suitable for treating infectious diseases. To isolate the $P$. aeruginosa phages, enrichment cultures were used. The lytic activity spectrum was confirmed by spot testing on $40 P$. aeruginosa strains. Whole-genome sequencing was performed using lllumina MiSeq instrument. Phylogenetic analysis was done using VICTOR tool. Isolated phages vB_PaeA-55-1w and vB_PaeM-198 from Autographiviridae and Myoviridae families, respectively, had a broad spectrum of Iytic activity (about 50\% each), including lysis of MDR strains. The genomes vB_PaeA-55-1w and VB_PaeM-198 comprise double-stranded DNA of 42.5 and $66.3 \mathrm{kbp}$ in length, respectively. Open reading frames were annotated for both phages (52 for vB_PaeA-55-1w, and 95 for vB_PaeM-198), no integrases and toxins were detected. On a phylogenetic tree, vB_PaeA-55-1w phage was clustered with phages from the Phikmvvirus genus (Autographiviridae family), which are also used in phage therapy. vB_PaeM-198 phage was clustered with phages from the Pbunavirus genus (Myoviridae family). vB_PaeA-55-1w and vB_PaeM-198 phages could be considered as candidates for phage therapy and may be used to treat infections caused by MDR $P$. aeruginosa.

Keywords: Pseudomonas aeruginosa, virulent bacteriophages, phage therapy, Autographiviridae, Myoviridae, whole genome sequencing, phylogenetic analysis Funding: The study was supported by the State Assignment on the Development of a personalized approach to the therapy of infections using virulent bacteriophages (Code: Bacteriophage) (Russia).

Acknowledgments: the authors thank the Center for Precision Genome Editing and Genetic Technologies for Biomedicine, the Federal Research and Clinical Center of Physical-Chemical Medicine of the Federal Medical Biological Agency for their help with sequencing the genomes of bacteriophages.

Author contribution: Kornienko MA — study plan, data collection and processing, article authoring; Kuptsov NS — data collection and processing, article authoring; Danilov DI, Gorodnichev RB, Malakhova MV, Veselovsky VA — data collection; Bespiatykh DA — data processing, Shitikov EA — research plan, data processing, article authoring; llina EN — research plan, article authoring.

Compliance with ethical standards: the experiment was carried out in compliance with the Sanitary and Epidemiological Rules SP 1.3.2322-08 "Safe work with microorganisms of III-IV pathogenicity (hazardousness) groups and pathogens of parasitic diseases"; Sanitary and Epidemiological Rules SP 1.3.2518-09 "Amendments and additions \#1 to the sanitary and epidemiological rules" Safe work with microorganisms of III-IV pathogenicity (hazardousness) groups and pathogens of parasitic diseases"; Sanitary and Epidemiological Rules SanPiN 2.1.7.2790-10 "Sanitary and epidemiological requirements for medical waste management"; Federal Clinical Recommendations "Rational use of bacteriophages in medical and anti-epidemic practice."

$\square$ Correspondence should be addressed: Maria A. Kornienko

Malaya Pirogovskaya, 1a, Moscow, 119435; kornienkomariya@gmail.com

Received: 19.07.2021 Accepted: 05.08.2021 Published online: 18.09.2021

DOI: $10.47183 / \mathrm{mes} .2021 .027$

\section{ВЫДЕЛЕНИЕ И ХАРАКТЕРИСТИКА БАКТЕРИОФАГОВ PSEUDOMONAS AERUGINOSA - ПОТЕНЦИАЛЬНЫХ АГЕНТОВ ДЛЯ ФАГОВОЙ ТЕРАПИИ}

М. А. Корниенко $凶$, Н. С. Купцов, Д. И. Данилов, Р. Б. Городничев, М. В. Малахова, Д. А. Беспятых, В. А. Веселовский, Е. А. Шитиков, Е. Н. Ильина

Федеральный научно-клинический центр физико-химической медицины Федерального медико-биологического агентства, Москва, Россия

Одним из патогенов, характеризующихся критическим показателем доли штаммов с множественной лекарственной устойчивостью (МЛУ), является Pseudomonas aeruginosa. В качестве альтернативы антибиотикам при терапии инфекций, вызванных штаммами с МЛУ, рассматривают фаготерапию. Целью исследования было выделить и охарактеризовать бактериофаг P. aeruginosa, потенциально пригодный для терапии инфекционных заболеваний. Выделение проводили методом накопительных культур. Спектр литической активности устанавливали спот-тестированием на коллекции из 40 штаммов P. aeruginosa. Полногеномное секвенирование выполняли на платформе MiSeq (lllumina). Филогенетический анализ геномов проводили с помощью VICTOR. Выделенные бактериофаги vB_PaeA-55-1w и vB_РaeM-198, принадлежащие к семействам Autographiviridae и Mуоviridae соответственно, обладали широким спектром литической активности (около 50\% каждый), в том числе вызывали лизис штаммов с МЛУ. Геномы vВ_РаеА-55-1W и vB_PaеM-198 представлены двухцепочечной ДНК длиной 42,5 и 66,3 т.п.н. соответственно. В составе геномов аннотировано 52 (vB_РаеА-55-1w) и 95 (vB_PaeM-198) открытых рамок считывания, среди них гены интеграз и токсинов не обнаружены. На филогенетическом древе vВ_РаеА-55-1w располагался в кластере совместно с бактериофагами рода Phikmvvirus семейства Autographiviridae, в том числе с используемыми в фаготерапии, а vВ_ PaeM-198 входил в кластер, включающий бактериофаги рода Pbunavirus семейства Myoviridae. Бактериофаги vB_РaeA-55-1w и vB_РaeM-198 можно рассматривать в качестве кандидатов для применения в фаготерапии, в том числе и для лечения инфекций, вызванных штаммами P. аегиginosa с МлУ. Ключевые слова: Pseudomonas aeruginosa, вирулентные бактериофаги, фаготерапия, Autographiviridae, Муоviridae, полногеномное секвенирование, филогенетический анализ

Финансирование: исследование выполнено за счет средств, предоставленных для выполнения государственного задания «Разработка персонализированного подхода терапии инфекционных процессов с применением вирулентных бактериофагов» (ШИФР: Бактериофаг).

Благодарности: авторы благодарят Центр высокоточного редактирования и генетических технологий для биомедицины ФГБУ ФНКЦ ФХМ ФМБА России за секвенирование геномов бактериофагов.

Вклад авторов: М. А. Корниенко - план исследований, набор и обработка данных, написание статьи; Н. С. Купцов - набор и обработка данных, написание статьи; Д. И. Данилов, Р. Б. Городничев, М. В. Малахова, В. А. Веселовский - набор данных; Д. А. Беспятых - обработка данных, Е. А. Шитиков - план исследований, обработка данных, написание статьи; Е. Н. Ильина — план исследований, написание статьи.

Соблюдение этических стандартов: экспериментальная работа выполнена с соблюдением норм Санитарно-эпидемиологических правил «Безопасность работы с микроорганизмами III-IV групп патогенности (опасности) и возбудителями паразитарных болезней» СП 1.3.2322-08; Санитарно-эпидемиологических правил СП 1.3.2518-09 - «Дополнения и изменения № 1 к санитарно-эпидемиологическим правилам «Безопасность работы с микроорганизмами III-IV групп патогенности (опасности) и возбудителями паразитарных болезней» СП 1.3.2322-08; Санитарноэпидемиологических правил «Санитарно-эпидемиологические требования к обращению с медицинскими отходами» СанПиН 2.1.7.2790-10, а также Федеральных клинических рекомендаций «Рациональное применение бактериофагов в лечебной и противоэпидемической практике».

$\bowtie$ Для корреспонденции: Мария Андреевна Корниенко

ул. Малая Пироговская, д. 1а, г. Москва, 119435; kornienkomariya@gmail.com

Статья получена: 19.07.2021 Статья принята к печати: 05.08.2021 Опубликована онлайн: 18.09.2021

DOI: $10.47183 /$ mes.2021.027 
According to the World Health Organization, antibiotic resistance is rising to dangerously high levels in all parts of the world [1]. Gram-negative bacteria, including Pseudomonas aeruginosa, occupy the first places in the global priority list of antibioticresistant bacteria posing the greatest threat to human health [1]. The bacteria of this species are ubiquitous, their genetic plasticity and environmental adaptability are high. The wide variety of pathogenicity mechanisms often makes the infection general in cases of infestation with $P$. aeruginosa strains [2]. $P$. aeruginosa causes a wide range of diseases, from intoxication to extensive pyoinflammatory processes and septic shock [2]. According to AMRmap portal, the share of $P$. aeruginosa isolates, which occupy the top lines in the list of most common nosocomial pathogens in Russia, was $16.83 \%$ among all such pathogens isolated in 2015-2020 [3]. Besides, about 30\% of $P$. aeruginosa strains circulating in the population are multidrugresistant (MDR), i.e., they are resistant to at least one antibiotic drug out of three or more antibiotic groups, and about 15\% of the circulating $P$. aeruginosa strains show extreme drug resistance (XDR), i.e., they are resistant to at least one antibiotic from all groups of antibiotics, with the exception of 1-2 groups; these factors drive the related patient mortality up [4].

An urgent task currently is to develop alternative, nonantibiotic treatments for infectious diseases caused by MDR and XDR pathogens. One of the most promising alternatives are virulent bacteriophages, which are the basis of phage therapy [5]. The promise is in the capability of virulent bacteriophages to lyse both antibiotic-sensitive and antibiotic-resistant strains of bacteria. In addition, bacteriophages do not cause toxic and allergic side effects, have no contraindications [6] and can be prescribed to pregnant women in combination with other medications [7].

A number of reports and preclinical and clinical trials [8, 9] confirm the success of phage therapy against $P$. aeruginosa infections both in animals and humans. There are several commercial therapeutic drugs designed to counter infections caused by $P$. aeruginosa that are produced in Russia: Pseudomonas aeruginosa bacteriophage, Intesti-bacteriophage, Polyvalent purified pyobacteriophage (Microgen; Russia).

Despite the availability of bacteriophage preparations active against $P$. aeruginosa and the successful experience of their use, phage collections need to be constantly updated, as the specifics of modern phage therapy require. Since virulent bacteriophages have a rather narrow specificity and usually target only several strains, updating the collections means extending them with phages that cause lysis of current bacterial strains. Moreover, there are reported cases [10] when bacteria mutate and acquire resistance to bacteriophages [10]. Isolation of new bacteriophages and their inclusion in the composition of therapeutic drugs solves this problem.

In connection with the above, the purpose of this work is to isolate and characterize $P$. aeruginosa bacteriophages that can be used to treat infectious diseases.

\section{METHODS}

\section{Bacterial strains}

The study used $P$. aeruginosa strains $(n=40)$ selected from the collection of bacterial strains of the laboratory of molecular genetics of microorganisms of the Federal Research and Clinical Center of Physical-chemical Medicine of Federal Medical Biological Agency of Russia. The strains of the collection were characterized by the profile of drug susceptibility (to ceftriaxone, gentamicin, ciprofloxacin, and meropenem), as well as by genotypes according to the results of multilocus sequence typing (MLST) [11]. The bacteria were cultivated for 18-24 $\mathrm{h}$ in the lysogeny broth (LB) nutrient medium (Oxoid; UK) at $37^{\circ} \mathrm{C}$.

\section{Isolation of bacteriophages}

The bacteriophages were isolated by enriching cultures from natural sources (sewage, water samples from various rivers) with $P$. aeruginosa strains PA55 and PA198 (Table 1). A sample of water $(50 \mathrm{ml})$ was drawn through a Millipore filter with a polyvinylidene fluoride membrane, pore diameter of $0.45 \mu \mathrm{m}$ (Merck Millipore; USA), and then two-fold LB broth was added to it. Subsequently, $300 \mathrm{ml}$ of an overnight culture of the host strain was added and incubated on a shaker at $37^{\circ} \mathrm{C}$ for $18 \mathrm{~h}$. After cultivation, bacterial cells were centrifuged for 10 minutes at $3500 \mathrm{~g}$ to achieve precipitation. The supernatant was put through a Millipore filter with a polyethersulfone membrane and a pore diameter of $0.22 \mu \mathrm{m}$ (Merck Millipore; USA). Individual bacteriophages were obtained by sequential (threefold) isolation from individual negative colonies. Further on, bacteriophages were grown in $50 \mathrm{ml}$ of LB broth containing $300 \mu \mathrm{l}$ of the bacterial strain overnight culture. The concentration of the bacteriophage in the phage lysate was estimated by the standard Grazia titration method [12].

\section{Bacteriophage lytic capability range determination}

Bacteriophage lytic capability range was determined by spot testing. Phagolysates with a titer of $3 \times 10^{6} \mathrm{PFU} / \mathrm{ml}$ (plaqueforming units per $\mathrm{ml}$ ) were used in the tests with the aim to prevent non-specific lysis. An overnight culture $\left(10^{10} \mathrm{CFU} / \mathrm{ml}\right)$ of the tested bacterial strain was sequentially diluted in LB broth to a cell concentration of $10^{6} \mathrm{CFU} / \mathrm{ml}$, then $0.1 \mathrm{ml}$ thereof was mixed with $5 \mathrm{ml}$ of semisolid LB agar (0.6\% agar) and added to a Petri dish containing a thin layer of LB agar (1.5\% agar). After solidification of the semisolid agar, a drop $(5 \mu \mathrm{L})$ of the studied bacteriophage was applied to the dish's surface. Petri dishes were incubated at $37^{\circ} \mathrm{C}$ for $18-24 \mathrm{~h}$. Lytic capability was assessed visually: the bacterial strain was considered sensitive to the bacteriophage in case there appeared a transparent spot or separate negative colonies. In the absence of such a lysis spot or if it was opaque the bacterial strain was classified as resistant.

Table 1. Characteristics of $P$. aeruginosa bacteriophage host strains

\begin{tabular}{|c|c|c|c|c|c|}
\hline \multirow{2}{*}{ Strain } & \multirow{2}{*}{ MLST sequence type } & \multicolumn{4}{|c|}{ Antibacterial susceptibility pattern } \\
\cline { 3 - 6 } & & ceftriaxone & gentamicin & ciprofloxacin & meropenem \\
\hline PA198 & ST508 & R & S & S & R \\
\hline PA55 & ST2690 & R & S & S & S \\
\hline
\end{tabular}


Table 2. Genetic characteristics of the collection strains and range of the hosts of vB_PaeA-55-1w and vB_PaeM-198 bacteriophages

\begin{tabular}{|c|c|c|c|}
\hline MLST sequence typing & Total number of strains & $\begin{array}{l}\text { Share of strains lysed by } \\
\text { vB_PaeA-55-1w, \% }\end{array}$ & $\begin{array}{c}\text { Share of strains lysed by vB_ } \\
\text { PaeM-198, \% }\end{array}$ \\
\hline ST12 & 5 & 0 & 100 \\
\hline ST17 & 1 & 0 & 0 \\
\hline ST186 & 1 & 100 & 100 \\
\hline ST198 & 2 & 100 & 50 \\
\hline ST207 & 2 & 100 & 0 \\
\hline ST233 & 1 & 100 & 100 \\
\hline ST235 & 1 & 0 & 0 \\
\hline ST244 & 4 & 100 & 75 \\
\hline ST266 & 1 & 100 & 100 \\
\hline ST357 & 1 & 100 & 0 \\
\hline ST395 & 1 & 0 & 0 \\
\hline ST483 & 1 & 0 & 0 \\
\hline ST498 & 1 & 0 & 0 \\
\hline ST499 & 2 & 100 & 100 \\
\hline ST508 & 1 & 0 & 100 \\
\hline ST569 & 1 & 0 & 0 \\
\hline ST589 & 1 & 0 & 100 \\
\hline ST654 & 3 & 33,3 & 0 \\
\hline ST1094 & 1 & 100 & 100 \\
\hline ST1292 & 1 & 0 & 0 \\
\hline ST1527 & 1 & 0 & 0 \\
\hline ST2427 & 1 & 0 & 0 \\
\hline ST2690 & 1 & 100 & 100 \\
\hline Unique type $15-5-11-8-4-4-1^{*}$ & 2 & 0 & 50 \\
\hline Unique type $15-2-11-3-3-38-3^{*}$ & 2 & 100 & 50 \\
\hline Unique type $17-5-12-3-14-4-7^{\star}$ & 1 & 0 & 0 \\
\hline
\end{tabular}

Note: * - the allele numbers of genes included in the standard MLST pattern (arcC-aroE-glpF-gmk-pta-tpi-yql) [21] are indicated for each unique sequence type.

\section{Isolation of bacteriophage DNA and whole genome sequencing}

Total bacteriophage DNA was isolated by phenol-chloroform extraction method [13] with preliminary enzymatic treatment of phage lysates with RNase A, DNase I, and proteinase K (Thermo Fisher Scientific; USA) in accordance with the manufacturer's instructions.

The library was prepared with 250 ng of genomic DNA. Covaris S220 System (Covaris; United States) enabled DNA fragmentation to 400-500 bps. Quality of the fragmented samples was assessed with Agilent 2100 bioanalyzer (Agilent; USA) in accordance with the manufacturer's instructions. The NEBNext Ultra II DNA Library Prep Kit (New England Biolabs; USA) was used to prepare genomic libraries, and the NEBNext Multiplex Oligos kit for Illumina (96 index primers, New England Biolabs; USA) was used to index the libraries. Quantitative analysis of the libraries was performed with the help of Quant-iT DNA Assay Kit, High Sensitivity (Thermo Scientific; USA). Sequencing was done with the MiSeq system and MiSeq Reagent Nano Kit v2 (500 cycle) (Illumina; USA) in accordance with the manufacturer's recommendations.

\section{Bioinformatic analysis of bacteriophage genomes}

Prokka v1.14.6 software [14] was used to assemble the whole genome sequences of bacteriophages. Rapid Annotation using Subsystem Technology (RAST) enabled bacteriophage genome annotation [15]. The functions of some open reading frames (ORF) have been predicted using BLASTP (https:// blast.ncbi.nlm.nih.gov/Blast.cgi) and HHpred (https://toolkit. tuebingen.mpg.de/\#/tools/ hhpred). Transport RNAs (tRNAs) were searched for with ARAGORN software [16]. The obtained genomes were deposited into the GenBank database under numbers MZ553931 and MZ553930 for bacteriophages vB_ PaeA-55-1w and vB_PaeM-198, respectively.

The taxonomy of the studied bacteriophages was determined based on the homology of their genomic sequences with the sequences of bacteriophages registered in the GenBank database using the BLASTN service (https://blast.ncbi.nlm.nih.gov/Blast. cgi). Naming of the bacteriophages followed ICTV (International Committee on Taxonomy of Viruses) recommendations [17] and depended on their taxonomic position.

Phylogenetic analysis of the genomes was performed with the help of VICTOR online tool (Genome-BLAST Distance Phylogeny); the settings were as recommended for prokaryotic viruses [18]. The branches were processed with FASTME [19] according to the DO formula, visualization done with FigTree [20]. For bacteriophage vB_PaeA-55-1w, we used the following bacteriophage genomes (GenBank database numbers) for comparison: NC_054890, NC_047953, NC_047967, NC_048201, NC_047965, NC_026602, NC_027375, NC_047956, NC_047957, NC_031014, NC_016764, NC_030923, NC_028836, NC_013638, NC_004665, 
A

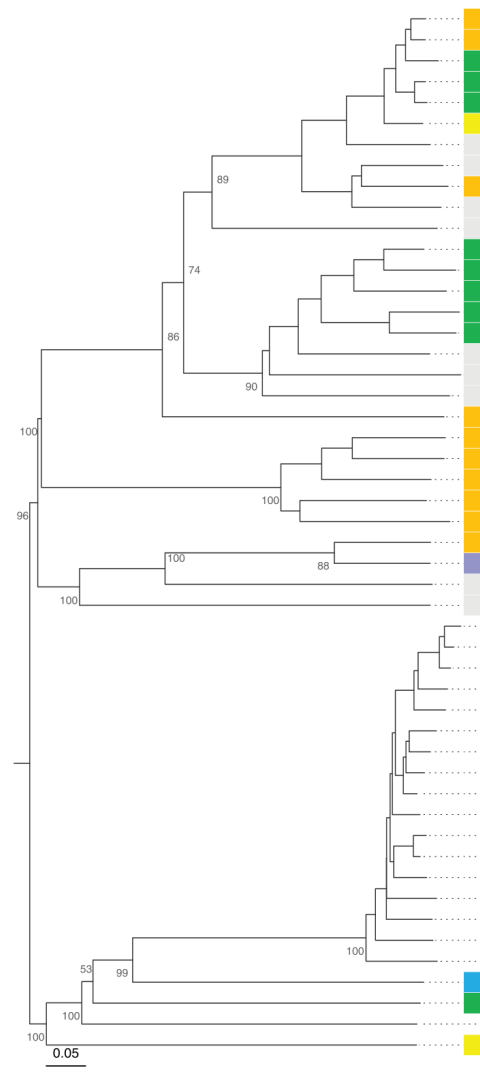

phiPSA2 NC_024362,
phiPsa17 NC.047747

PH1_ERZ-2017_MG250485

KNP_NC__047827.1

WRT_NC.047826.

gh-1 1 NC_ 004665.1

17A_NC_0 088201.1
shl2_NC_048200.1

shli__NC_048200.11

Henninger_NC_No47922.1

PspYZU08_NC_047981.1

PP-10_NC_027292.1

philiB-FF7A_NC_015264.

PFP1_NC_047997.1

UNO-SLW1_NC_NC47878.1

PPPW-4_NC_.023005.1

phi15 NC 015208.1

V_PSPYP_3MF5_NC__5 44890.1

Alpheus_NC__047957.1
Nerthus_NC 047955.1

- Acerthus_NC_. 047955.11

Nord_NC__047954.1.

Uiligo_NC__047894.1

Andromeda_NC_031014,

Bi7_-NC. 016764.1

PollyC_NC_042104.1
- vSW-3_NC_041885.1

phinFS_NC_0478552.1

phiKMV_NC_.005045.1

PaeP PPA.ABTNL NC 027375.

MPK7

UZ19_NC_010326.1

3 PaeA.55_1W

MPK6_NC_022746.1

RLP_NC_048168.1

PT5_NC 0 011105.1

VB_PaeP_PAO1_1-115
DL62_NC_028836.1 BPPae_-130_113_NC__4047953 phikF77_NC 0 012418.1

(1)

(

KKA1_NC_.009396,

YMC11/06:C171_PPU
Ghunavirus

Pijolavirus

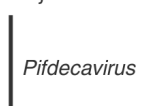

Phutvirus

Troedvirus
Warsawvirus

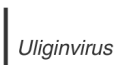

Uliginvirus

| Bifseptvirus

Pollyceevirus
Napahaivirus

$$
\mid
$$

Kirikabuvirus
Tunggulvirus Stubburvirus
Kantovirus
B

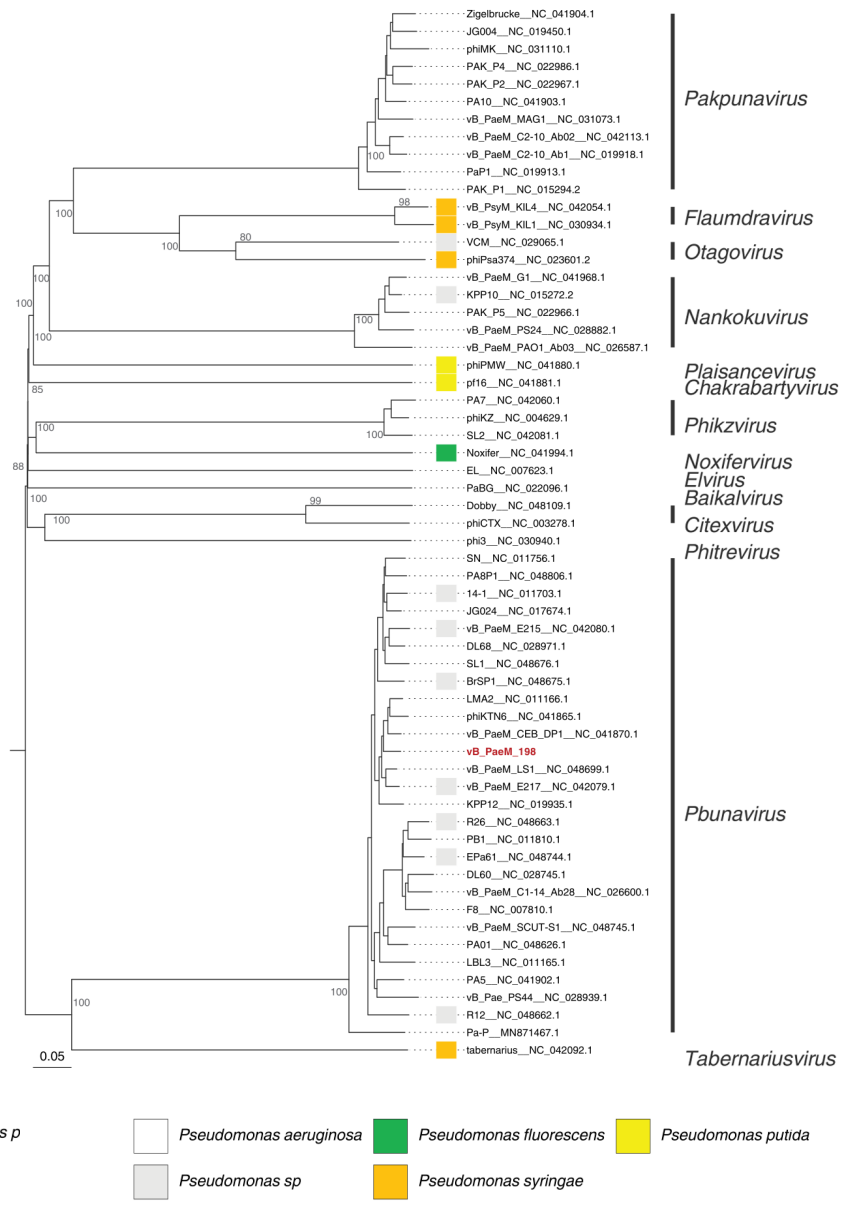

Fig. 1. Phylogenetic analysis of the whole genome sequences of Pseudomonas spp bacteriophages $\mathrm{A}$. Phylogenetic tree of the Autographiviridae family bacteriophages $(n=50)$. B. Phylogenetic tree of the Myoviridae family bacteriophages $(n=60)$. Bacteriophages vB_PaeA-55-1W and vB_PaeM-198 are marked in red

NC_047922, NC_015264, NC_012418, NC_047827, NC_009936, NC_009935, NC_010326, NC_022746, NC_022091, NC_047955, NC_047852, NC_047954, NC_047933, NC_047952, NC_027292, MG250485, NC_047997, NC_015208, NC_005045, NC_047747, NC_024362, NC_021062, NC_042104, NC_028661, NC_023005, NC_047981, NC_011107, NC_011105, NC_048168, NC_048200, NC_047894, NC_047873, NC_041885, NC_047826. For bacteriophage vB_PaeM-198, the genomes were as follows: NC_048675, NC_048744, NC_048626, NC_048662, NC_048663, NC_048676, NC_048745, NC_011703, NC_026587, NC_026600, NC_042113, NC_019918, NC_028745, NC_028971, NC_048109, NC_041870.1, NC_042080, NC_042079, NC_007623, NC_007810, NC_041968, NC_019450, NC_017674, NC_042054, NC_030934, NC_015272, NC_019935, NC_041865, NC_011165, NC_011166, NC_048699.1, NC_031073, NC_031073, MN871467, NC_041994, NC_041903, NC_041902.1, NC_042060, NC_048806, NC_022096, NC_015294, NC_022967.1, NC_022966, NC_022986, NC_019913, NC_011810, NC_041881, NC_030940, NC_003278, NC_004629, NC_031110, NC_041880, NC_028882, NC_028939, NC_023601, NC_042081, NC_042081, NC_042081, NC_011756, NC_042092, NC_029065, NC_041904.

Modular structure of the genomes was determined based on the annotation and when establishing homology of the nucleotide sequences of individual ORFs with BLASTN (https:// blast.ncbi.nlm.nih.gov/Blast.cgi).

\section{RESULTS}

\section{Isolation of bacteriophages and characterization of the lytic capability range}

To isolate bacteriophages active against the $P$. aeruginosa species we selected strains PA55 and PA198 from the bacterial strains collection of the Federal Research and Clinical Center of Physical-Chemical Medicine (Table 1). These host strains allowed isolating two bacteriophages, which were later named vB_PaeA-55-1w and vB_PaeM-198. As for their lytic capability, vB_PaeA-55-1w phage caused lysis of 19 strains of the collection (47.5\%) and vB_PaeM-198 lysed 20 strains (50\%) (Table 2). It should also be noted that out of 17 MDR strains vB_PaeA-55-1w lysed 8 (47\%) and vB_PaeM-198 - 6 (35\%).

\section{Whole genome sequencing of the bacteriophages}

Detailed characterization of the studied bacteriophages relied on the whole genome sequencing data and annotation thereof. Genomes of the bacteriophages were double-stranded DNA $42.5 \mathrm{kbp}$ (vB_PaeA-55-1w) and $66.3 \mathrm{kbp}$ (vB_PaeM-198) long. Bacteriophage vB_PaeA-55-1w encoded 52 ORFs, while vB_PaeM-198 encoded 95 ORFs. None of the analyzed bacteriophages contained tRNA in the genome.

Taxonomic position of the bacteriophages and their closest relative were established by comparing the obtained genomewide sequences with the genomes available in the Genbank database. Bacteriophage vB_PaeA-55-1w belonged to the 

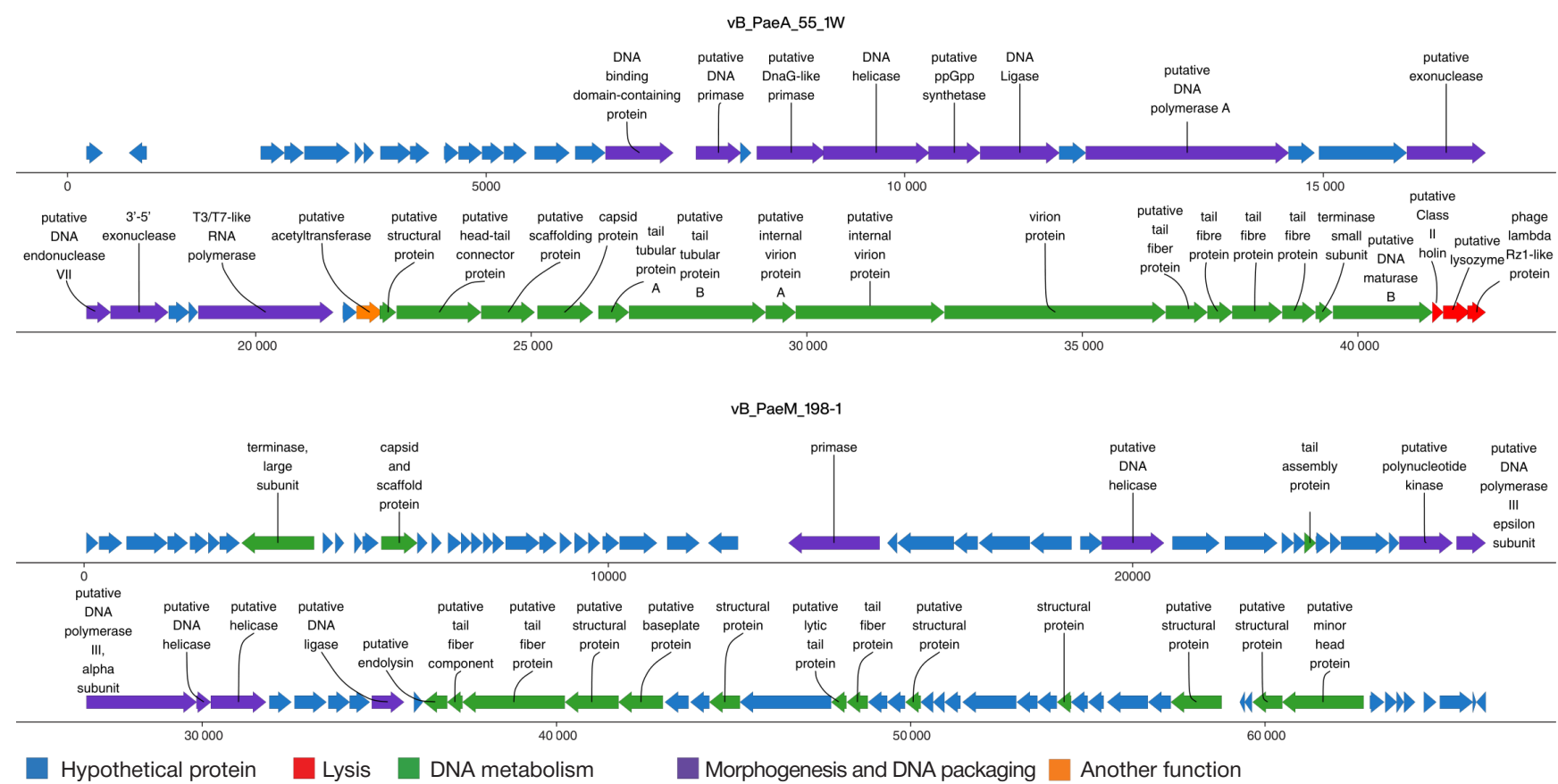

Hypothetical protein

Lysis

DNA metabolism

Morphogenesis and DNA packaging

Fig. 2. Main structural modules of the genomes of vB_PaeA-55-1w and vB_PaeM-198 P. aeruginosa bacteriophage

Phikmvvirus genus of the Autographiviridae family, and the closest genome corresponded to the Pseudomonas phage MYY9 (95\% similarity, 97.59\% alignment length, Genbank number - MW406975.1). Bacteriophage vB_PaeM-198 belonged to the Pbunavirus genus of the Myoviridae family and was highly similar to Pseudomonas phage phiKT28 (99\% similarity, 96.34\% alignment length, Genbank number — KP340287.1).

\section{Phylogenetic analysis of Pseudomonas spp. bacteriophages}

To position the studied bacteriophages within their respective families we relied on the reference genomes recommended by ICTV [17]. Phylogenetic analysis of the Autographiviridae family included 50 genomes of Pseudomonas spp. bacteriophages (Fig. 1A), that of the Myoviridae family - 60 genomes (Fig. 1B).

Two large clusters can be identified on the phylogenetic tree of Pseudomonas spp. bacteriophages belonging to the Autographiviridae family (Fig. 1A). The first cluster includes bacteriophages that have $P$. aeruginosa species as hosts, and Pseudomonas agarici, Pseudomonas putida and Pseudomonas fluorescens bacteriophages (one of each). It should be noted that phylogenetic analysis results match taxonomic classification of these viruses. Within the first cluster, $P$. aeruginosa bacteriophages are grouped separately and belong to the Phikmvvirus genus, including the investigated vB_PaeA-55-1w bacteriophage. The only exception is Pseudomonas phage LKA1, which has its own branch on the phylogenetic tree. The taxonomy has this bacteriophage belonging to another Stubburvirus genus. As for Pseudomonas agarici, Pseudomonas putida and Pseudomonas fluorescens in the first large cluster, each of them also occupies an individual branch of the phylogenetic tree and belongs to a separate taxon, namely, genera Kirikabuvirus, Tunggulvirus, and Kantovirus, respectively. The second large cluster on the phylogenetic tree is comprised of the bacteriophages that have Pseudomonas syringae, Pseudomonas tolaasii, Pseudomonas putida, Pseudomonas fluorescens as hosts, as well as Pseudomonas genus bacteria with unestablished species identity. Phylogenetic subgroups of the second cluster are also consistent with genera of their bacteriophages, namely Pifdecavirus, Ghunavirus, Troedvirus, Pollyceevirus, Phutvirus, Napahaivirus, Pijolavirus, Pifdecavirus, Bifseptvirus, Uliginvirus. It should be noted that several genera within the family had hosts belonging to different species: Bifseptvirus - hosts of $P$. syringae and P. tolaasii; Ghunavirus - hosts of $P$. fluorescens, $P$. putida, $P$. syringae.

$P$. aeruginosa bacteriophages of the Myoviridae family were found in different parts of the phylogenetic tree and corresponded to seven genera: Baikalvirus, Citexvirus, Elvirus, Nankokuvirus, Pakpunavirus, Pbunavirus and Phikzvirus (Fig. 1B). The studied vB_PaeM-198 bacteriophage shares the position on the phylogenetic tree with 26 other Pbunavirus bacteriophages. P. fluorescens, P. putida, P. syringae bacteriophages of the Myoviridae families belong to 6 different genera: Chakrabartyvirus, Flaumdravirus, Noxifervirus, Otagovirus, Plaisancevirus and Tabernariusvirus.

\section{Modular structure of the vB_PaeA-55-1w and vB_PaeM-198 bacteriophages}

To describe the genomic organization of bacteriophages vB_PaeA-55-1w and vB_PaeM-198, we analyzed functional modules of the genomes. It should be noted that the number of genes the functions of which were identified was higher for the vB_PaeA-55-1w bacteriophage $(n=30 / 52,58 \%)$ than for vB_PaeM-198 ( $n=24 / 95,25 \%)$ (Fig. 2). The analysis also yielded localization of the modules of nucleic acid metabolism and morphogenesis and packaging. The location of the lysis module was established for the vB_PaeA-55-1w bacteriophage. Targeted search revealed no known bacterial toxins and various integrases in the vB_PaeA-55-1 $\mathrm{w}$ and vB_ PaeM-198 genomes.

\section{DISCUSSION}

Due to antibiotic crisis associated with the spread of MDR and XDR bacteria, $P$. aeruginosa bacteriophages are used in therapeutic practice more and more often. Infections caused 
by $P$. aeruginosa are most often treated with phages of the Autographiviridae and Myoviridae families [22, 23]. For this study, we isolated Autographiviridae (vB_PaeA-55-1w) and Myoviridae (vB_PaeM-198) bacteriophages from natural sources; these bacteriophages offer a wide range of lysing capability ( $47.5 \%$ and $50 \%$, respectively), which is comparable to the $P$. aeruginosa bacteriophages of the corresponding families [24, 25]. It should be noted that the bacteriophages lysed various strains, which can make therapy more efficient with a phage cocktail that includes both of the studied bacteriophages.

It should also be emphasized that the bacteriophages caused lysis of the strains that belong to different sequence types, including ST235 $(n=1)$, ST244 $(n=4)$, and ST395 $(n=1)$. Isolates belonging to these sequence types are among the most widespread throughout the world; they are often associated with outbreaks of infectious diseases, and they have higher resistance to antibacterial drugs [26]. It seems interesting to further study the lytic capability of vB_PaeA-55-1w and vB_PaeM-198 on a collection of S. aureus strains of the high epidemic risk sequence types.

Current requirements for therapeutic drugs prescribe describing them in detail, and in the case of bacteriophages, it is also necessary to determine their genomic sequences [27] and thus confirm the virulent nature thereof through showing there are no integrase genes in their genomes. Temperate bacteriophages are not used for therapy because they can facilitate transfer of genes of bacterial toxins and determinants of antibiotic resistance in the bacterial population [27]. Besides, in order to assess therapeutic safety of a bacteriophage its genome is searched for genes of known toxins [27].

The studied bacteriophages (both families) were shown to have typical modular genome structure [24, 28], including a nucleic acid metabolism module, a morphogenesis and packaging module. In addition, localization of the lysis module was established for vB_PaeA-55-1w (Autographiviridae). In case of the vB_PaeM-198 (family Myoviridae) bacteriophage, no genes highly similar to the known genes of lysines or cholines were found. Both studied bacteriophages were found to have no lysogeny module with integrase genes, which confirms their virulent nature, nor were they established to contain known genes of toxins, which makes them potentially usable in therapy.

Based on the results of phylogenetic analysis of Pseudomonas spp. bacteriophages belonging to the Autographiviridae and Myoviridae families, it was shown that $P$. aeruginosa bacteriophages, regardless of their family, form separate clusters on phylogenetic trees that correspond to genera Phikmvvirus and Stubburvirus (family Autographiviridae), as well as Elvirus, Nankokuvirus, Pakpunavirus, Pbunavirus, Phikzvirus, Phitrevirus (Myoviridae family). This fact indicates that $P$. aeruginosa bacteriophages are species-specific. On a separate note, bacteriophages previously described and used in phage therapy (phiKMV, PPA-ABTNL, MPK6, RLP), including $\Phi \mathrm{NH}-4$ (Pbunaviruses) and PAK_P1 (Pakpunavirus), have shown their efficacy in animal models [29, 30], and they also cluster together with the studied vB_PaeA-55-1w and vB_PaeM-198 bacteriophages.

\section{CONCLUSIONS}

Based on the analysis performed, bacteriophages vB_PaeA55-1w and vB_PaeM-198 can be recommended for use in phage therapy, including the protocols designed to combat infections caused by MDR strains of $P$. aeruginosa.

\section{References}

1. Tacconelli E, Carrara E, Savoldi A, Harbarth S, Mendelson M, Monnetet DL, et al. Discovery, research, and development of new antibiotics: the WHO priority list of antibiotic-resistant bacteria and tuberculosis. Lancet Infect Dis. 2018; 18 (3): 318-27.

2. Horcajada JP, Montero M, Oliver A, Sorlí L, Luque S, GómezZorrilla S, et al. Epidemiology and treatment of multidrug-resistant and extensively drug-resistant Pseudomonas aeruginosa infections. Clin Microbiol Rev. 2019; 32 (4).

3. Kuzmenkov AY, Trushin IV, Vinogradova AG, Avramenko AA, Sukhorukova MV, Malhotra-Kumar S, et al. AMRmap: an interactive web platform for analysis of antimicrobial resistance surveillance data in Russia. Front Microbiol. 2021; 12: 620002.

4. Pena C, Cabot G, Gómez-Zorrilla S, Zamorano L, OcampoSosa A, Murillas J, et al. Influence of virulence genotype and resistance profile in the mortality of Pseudomonas aeruginosa bloodstream infections. Clin Infect Dis. 2015; 60 (4): 539-48.

5. 2020 Antibacterial agents in clinical and preclinical development: an overview and analysis. Geneva: World Health Organization, 2021. Available from: https://www.who.int/publications/i/ item/9789240021303.

6. Gordillo Altamirano FL, Barr JJ. Phage therapy in the postantibiotic era. Clinical Microbiology Reviews. 2019; 32 (2): e00066-18. DOI: 10.1128/CMR.00066-18.

7. Akimkin VG, Darbeeva OS, Kolkov VF. Bakteriofagi: istoricheskie i sovremennye aspekty in primenenija: opyt i perspektivy. Klinicheskaja praktika. 2010; 1 (4): 48-54. Russian.

8. Chen F, Cheng X, Li J, Yuan X, Huang X, Lian M, et al. Novel lytic phages protect cells and mice against Pseudomonas aeruginosa infection. J Virol. 2021; 95 (8): e01832-20. DOI: 10.1128/ JVI.01832-20.
9. Jault P, Cheng X, Li J, Yuan X, Huang X, Lian M, et al. Efficacy and tolerability of a cocktail of bacteriophages to treat burn wounds infected by Pseudomonas aeruginosa (PhagoBurn): a randomised, controlled, double-blind phase 1/2 trial. Lancet Infect Dis. 2019; 19 (1): 35-45.

10. Oechslin F. Resistance development to bacteriophages occurring during bacteriophage therapy. Viruses. 2018; 10 (7): 351. DOl: 10.3390/v10070351.

11. Kuptsov NS, Kornienko MA, Gorodnichev RB, Danilov DI, Malakhova MV, Parfenova TV, et al. Efficacy of commercial bacteriophage products against ESKAPE pathogens. Bulletin of RSMU. 2020; (3): 18-24.

12. Mazzocco A, et al. Enumeration of bacteriophages using the small drop plaque assay system. Methods Mol Biol. 2009; 501: 81-85.

13. Sambrook J, Fritsch EF, Maniatis T. Molecular cloning: a laboratory manual. Cold Spring Harbor Laboratory Pr. 1989, 2200 p.

14. Seemann T. Prokka: Rapid prokaryotic genome annotation. Bioinformatics. Oxford University Press. 2014; 30 (14): 2068-9.

15. Aziz RK, et al. The RAST Server: Rapid annotations using subsystems technology. BMC Genomics. BioMed Central. 2008; 9: 75 .

16. Laslett D. ARAGORN, a program to detect tRNA genes and tmRNA genes in nucleotide sequences. Nucleic Acids Res. 2004; 32 (1): 11-16.

17. Lefkowitz EJ, et al. Virus taxonomy: The database of the International Committee on Taxonomy of Viruses (ICTV). Nucleic Acids Res. 2018: 46 (1): 708-17.

18. Meier-Kolthoff JP, Göker M. VICTOR: genome-based phylogeny and classification of prokaryotic viruses. Bioinformatics. 2017; 33 (21): 3396-404. 
19. Lefort V, Desper R, Gascuel O. FastME 2.0: A comprehensive, accurate, and fast distance-based phylogeny inference program. Mol Biol. 2015; 32 (10): 2798-800.

20. FigTree. Available from: http://tree.bio.ed.ac.uk/software/figtree/. (Data obrashhenija: 16.07.2021)

21. Enright $\mathrm{MC}$, et al. Multilocus sequence typing for characterization of methicillin-resistant and methicillin-susceptible clones of Staphylococcus aureus. J Clin Microbiol. 2000; 38 (3): 1008-15.

22. Alvi $I A$, et al. RLP, a bacteriophage of the family Podoviridae, rescues mice from bacteremia caused by multi-drug-resistant Pseudomonas aeruginosa. Arch Virol. 2020. 165 (6): 1289-97.

23. Farlow J, et al. Complete Genome Sequences of 10 Phages Lytic against Multidrug-Resistant Pseudomonas aeruginosa. Microbiol Resour. 2020. 9: 29.

24. Alvi IA, Asif M, Rehman S. A single dose of a virulent bacteriophage vB PaeP-SaPL, rescues bacteremic mice infected with multi drug resistant Pseudomonas aeruginosa. Virus Res. 2021; 292: 198250.

25. Adnan $\mathrm{M}$, et al. Isolation and characterization of bacteriophage to control multidrug-resistant Pseudomonas aeruginosa planktonic cells and biofilm. Biologicals. 2020; 63: 89-96.

26. Treepong $P$, et al. Global emergence of the widespread Pseudomonas aeruginosa ST235 clone. Clin Microbiol Infect. 2018; 24 (3): 258-66.

27. Principi N, Silvestri E, Esposito S. Advantages and Limitations of Bacteriophages for the Treatment of Bacterial Infections. Front Pharmacol. 2019; 10: 513

28. Guo $Y$, Chen $P$, Lin Z, Wang T. Characterization of Two Pseudomonas aeruginosa Viruses vB_PaeM_SCUT-S1 and vB_PaeM_SCUT-S2. Viruses. 2019; 11 (4): 318. DOI: 10.3390/ v11040318.

29. Alemayehu D, Casey PG, McAuliffe O, Guinane CM, Martin JG, Shanahan F, et al. Bacteriophages $\varphi \mathrm{MR} 299-2$ and $\varphi \mathrm{NH}-4$ can eliminate Pseudomonas aeruginosa in the murine lung and on cystic fibrosis lung airway cells. MBio. 2012; 3 (2): e00029-12. DOI: 10.1128/mBio.00029-12.

30. Debarbieux L, Leduc D, Maura D, Morello E, Criscuolo A, Grossi O, et al. Bacteriophages can treat and prevent Pseudomonas aeruginosa lung infections. J Infect Dis. 2010; 201 (7): 1096-104.

\section{Литература}

1. Tacconelli E, Carrara E, Savoldi A, Harbarth S, Mendelson M, Monnetet DL, et al. Discovery, research, and development of new antibiotics: the WHO priority list of antibiotic-resistant bacteria and tuberculosis. Lancet Infect Dis. 2018; 18 (3): 318-27.

2. Horcajada JP, Montero M, Oliver A, Sorlí L, Luque S, GómezZorrilla S, et al. Epidemiology and treatment of multidrug-resistan and extensively drug-resistant Pseudomonas aeruginosa infections. Clin Microbiol Rev. 2019; 32 (4).

3. Kuzmenkov AY, Trushin IV, Vinogradova AG, Avramenko AA Sukhorukova MV, Malhotra-Kumar S, et al. AMRmap: an interactive web platform for analysis of antimicrobial resistance surveillance data in Russia. Front Microbiol. 2021; 12: 620002.

4. Pena C, Cabot G, Gómez-Zorrilla S, Zamorano L, OcampoSosa A, Murillas J, et al. Influence of virulence genotype and resistance profile in the mortality of Pseudomonas aeruginosa bloodstream infections. Clin Infect Dis. 2015; 60 (4): 539-48.

5. 2020 Antibacterial agents in clinical and preclinical development: an overview and analysis. Geneva: World Health Organization, 2021. Available from: https://www.who.int/publications/i/ item/9789240021303.

6. Gordillo Altamirano FL, Barr JJ. Phage therapy in the postantibiotic era. Clinical Microbiology Reviews. 2019; 32 (2): e00066-18. DOI: 10.1128/CMR.00066-18.

7. Акимкин В. Г., Дарбеева О. С., Колков В.Ф. Бактериофаги: исторические и современные аспекты их применения: опыт и перспективы. Клиническая практика. 2010; 1 (4): 48-54.

8. Chen F, Cheng X, Li J, Yuan X, Huang X, Lian M, et al. Novel lytic phages protect cells and mice against Pseudomonas aeruginosa infection. J Virol. 2021; 95 (8): e01832-20. DOI: 10.1128/ JVI.01832-20.

9. Jault P, Cheng X, Li J, Yuan X, Huang X, Lian M, et al. Efficacy and tolerability of a cocktail of bacteriophages to treat burn wounds infected by Pseudomonas aeruginosa (PhagoBurn): a randomised, controlled, double-blind phase 1/2 trial. Lancet Infect Dis. 2019; 19 (1): 35-45.

10. Oechslin F. Resistance development to bacteriophages occurring during bacteriophage therapy. Viruses. 2018; 10 (7): 351. DOI: 10.3390/v10070351

11. Купцов Н. С. и др. Эфффективность препаратов бактериосрагов против патогенов группы ESKAPE. Вестник РГМУ. 2020; (3): $19-26$.

12. Mazzocco A, et al. Enumeration of bacteriophages using the small drop plaque assay system. Methods Mol Biol. 2009; 501: 81-85.

13. Sambrook J, Fritsch EF, Maniatis T. Molecular cloning: a laboratory manual. Cold Spring Harbor Laboratory Pr. 1989, 2200 p.

14. Seemann T. Prokka: Rapid prokaryotic genome annotation. Bioinformatics. Oxford University Press. 2014; 30 (14): 2068-9.

15. Aziz RK, et al. The RAST Server: Rapid annotations using

subsystems technology. BMC Genomics. BioMed Central. 2008; 9: 75 .

16. Laslett D. ARAGORN, a program to detect tRNA genes and tmRNA genes in nucleotide sequences. Nucleic Acids Res. 2004; 32 (1): 11-16.

17. Lefkowitz EJ, et al. Virus taxonomy: The database of the International Committee on Taxonomy of Viruses (ICTV). Nucleic Acids Res. 2018: 46 (1): 708-17.

18. Meier-Kolthoff JP, Göker M. VICTOR: genome-based phylogeny and classification of prokaryotic viruses. Bioinformatics. 2017; 33 (21): 3396-404.

19. Lefort V, Desper R, Gascuel O. FastME 2.0: A comprehensive, accurate, and fast distance-based phylogeny inference program. Mol Biol. 2015; 32 (10): 2798-800.

20. FigTree. Available from: http://tree.bio.ed.ac.uk/software/figtree/ (Дата обращения: 16.07.2021).

21. Enright $\mathrm{MC}$, et al. Multilocus sequence typing for characterization of methicillin-resistant and methicillin-susceptible clones of Staphylococcus aureus. J Clin Microbiol. 2000; 38 (3): 1008-15.

22. Alvi IA, et al. RLP, a bacteriophage of the family Podoviridae, rescues mice from bacteremia caused by multi-drug-resistant Pseudomonas aeruginosa. Arch Virol. 2020. 165 (6): 1289-97.

23. Farlow J, et al. Complete Genome Sequences of 10 Phages Lytic against Multidrug-Resistant Pseudomonas aeruginosa. Microbiol Resour. 2020. 9: 29.

24. Alvi IA, Asif M, Rehman S. A single dose of a virulent bacteriophage vB PaeP-SaPL, rescues bacteremic mice infected with multi drug resistant Pseudomonas aeruginosa. Virus Res. 2021; 292: 198250.

25. Adnan $\mathrm{M}$, et al. Isolation and characterization of bacteriophage to control multidrug-resistant Pseudomonas aeruginosa planktonic cells and biofilm. Biologicals. 2020; 63: 89-96.

26. Treepong $P$, et al. Global emergence of the widespread Pseudomonas aeruginosa ST235 clone. Clin Microbiol Infect. 2018; 24 (3): 258-66

27. Principi N, Silvestri E, Esposito S. Advantages and Limitations of Bacteriophages for the Treatment of Bacterial Infections. Front Pharmacol. 2019; 10: 513.

28. Guo Y, Chen P, Lin Z, Wang T. Characterization of Two Pseudomonas aeruginosa Viruses vB_PaeM_SCUT-S1 and VB_PaeM_SCUT-S2. Viruses. 2019; 11 (4): 318. DOI: 10.3390/ v11040318.

29. Alemayehu D, Casey PG, McAuliffe O, Guinane CM, Martin JG, Shanahan F, et al. Bacteriophages $\varphi \mathrm{MR} 299-2$ and $\varphi \mathrm{NH}-4$ can eliminate Pseudomonas aeruginosa in the murine lung and on cystic fibrosis lung airway cells. MBio. 2012; 3 (2): e00029-12. DOI: 10.1128/mBio.00029-12.

30. Debarbieux L, Leduc D, Maura D, Morello E, Criscuolo A, Grossi O, et al. Bacteriophages can treat and prevent Pseudomonas aeruginosa lung infections. J Infect Dis. 2010; 201 (7): 1096-104. 